LOFT TECHNICAL REPORT LTR 113-30 Rev. 1

EG\&G INTERNAL REPORT TR-860 Rev. 1

AUGUST 31,1978

\section{LOFT EMERGENCY CORE \\ COOLANT FACILITY PIPING REVIEW}

This report was prepared as an account of work
sponsored by the United States Government. Neither the
United States nor the United States Department of
Energy, nor any of their employees, nor any of their
contractors, subcontractors, or their employees, makes
any warranty, express or implied, or assumes any legal
liability or responsibility for the accuracy, completeness
or usefulness of any information, apparatus, product or
process disclosed, or represents that its use would not
infringe privately owned rights.

T. K. McKay/R. M. Fors

THIS REVISION COMPLETELY SUPERSEDES ALL PREVIOUS ISSUES OF LTR 113-30.

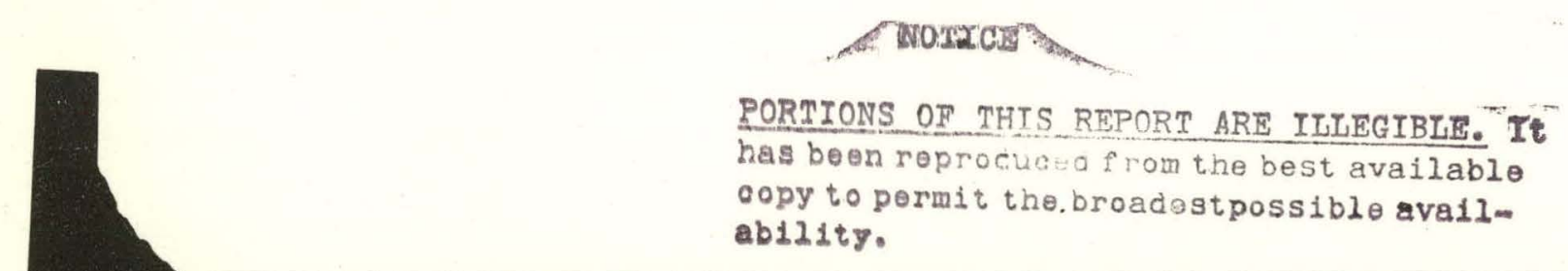

PORTIONS OF THIS REPORT ARE ILLEGIBLE. Tt

has been reprocuce a from the best available

ability.

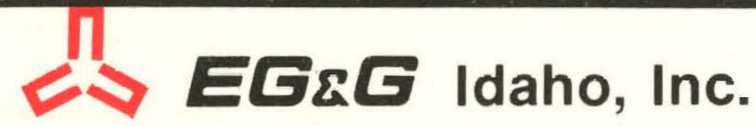

IDAHO NATIONAL ENGINEERING LABORATORY

\section{DEPARTMENT OF ENERGY}

IDAHO OPERATIONS OFFICE UNDER CONTRACT EY-76-C-07-1570 


\section{DISCLAIMER}

This report was prepared as an account of work sponsored by an agency of the United States Government. Neither the United States Government nor any agency Thereof, nor any of their employees, makes any warranty, express or implied, or assumes any legal liability or responsibility for the accuracy, completeness, or usefulness of any information, apparatus, product, or process disclosed, or represents that its use would not infringe privately owned rights. Reference herein to any specific commercial product, process, or service by trade name, trademark, manufacturer, or otherwise does not necessarily constitute or imply its endorsement, recommendation, or favoring by the United States Government or any agency thereof. The views and opinions of authors expressed herein do not necessarily state or reflect those of the United States Government or any agency thereof. 


\section{DISCLAIMER}

Portions of this document may be illegible in electronic image products. Images are produced from the best available original document. 
The following changes have been made to LTR 113-30:

1. On Page ii - Sentence added at end of Summary.

2. Pages 3 and 4 added.

3. Page 6a added - Modified-sketch for 150 "

4. Appendix $B$ added.

5. Page 20 - New hangers 1 through 5 deleted, Supports 6 and 9 changed from snubbers to special. U-Boit restraints. 


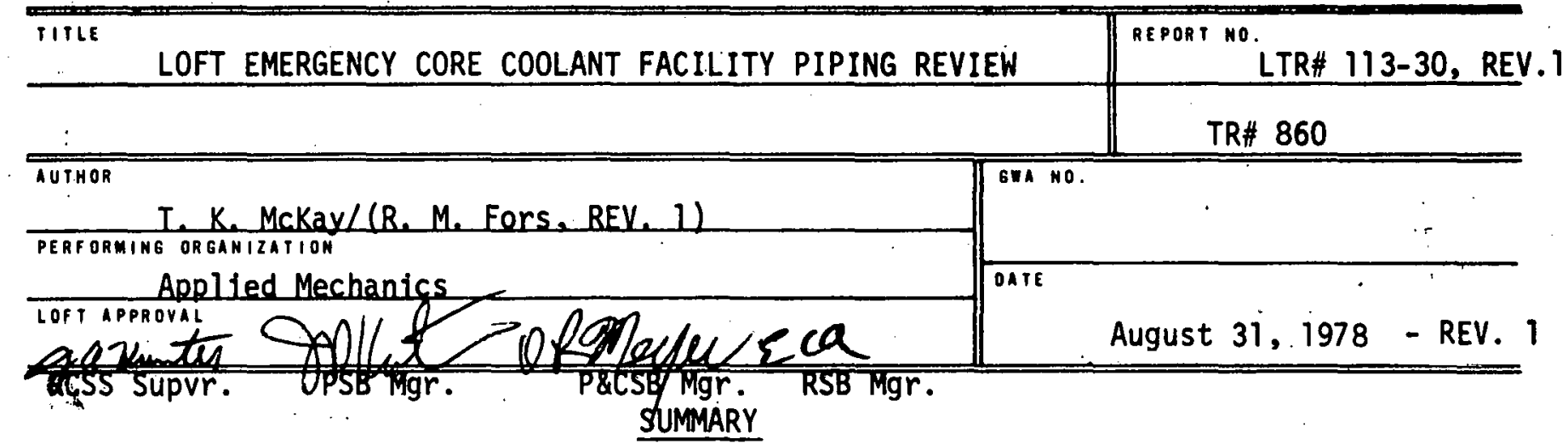

Using the Applied Mechanics Branch Piping Design Standard (LTR 10-21) as the analytical criterion, a review was made of all lines under two inches in diameter contained in the LOFT emergency core coolant facility not analyzed elsewhere, to determine adequacy of deadweight, seismic and thermal support. Some lines from other systems were also analyzed because of interconnection with the ECC System. ASME Code requirements are sptisfied through application of the design standard. Results indicated that some additional supports, as noted herein, will be necessary before the system can be considered adequately supported. In some instances existing restraints falled thermal analys is but since offset values were generated for an operating temperature of $200^{\circ} \mathrm{F}$, and the actual temperature will not exceed $150^{\circ} \mathrm{F}$ within the piping analyzed, no changes need be made to these restraints. During the review it was discovered that 1 ines attached to Line 1"-PC-57-VA needed additional supports. Lines associated with ISO \#1 have been reanalyzed by more igorous methods to simplify the supports for valves in this part of the ECC piping system.

\section{RECOMMENDATIONS}

1\%. Install the hangers as noted herein.

2. A stress analys is should be performed on lines associated with line 1"-PC-57-UA.

3. One hanger, as noted on isometric sketch number 3 , needs to be secured. 
The purpose of this review was to examine all remaining lines of the LOFT emergency core coolant facility piping outside of containment and with a diameter of less than two inches, not analyzed by ITT Grinnell Corporation. Because of a discrepancy on the Grinnell analysis, lines 3"-ECCV-10-A, 2"-ECCV-10-A and 2"-ECCV-11-A were included in this review. In addition, some lines from other systems which connected to the ECC piping were also examined, as 1 isted on the isometric sketches in this report. An on-site "walk-through" was made first to verify existing restraint and valve locations. Very short stub lines were eliminated by inspection. All remaining lines, together with the lines analyzed by Grinnell and lines being currently analyzed by R. M. Fors of the Applied Mechanics Branch constitute a complete analysis of the ECC facility piping as now listed in LOFT Specification P-1, Line Designation Tables.

Since all lines to be examined. had a normal operating temperature of $150^{\circ} \mathrm{F}$ or less, the Applied Mechanics Branch Piping Design Standard (LTR 10-21 by J.W. Muffett) was employed to determine adequate support configuration. This standard provides for satisfaction of the ASME Code requirements for Class 1 and Class 2 Nuclear Piping through comparison of the system under consideration to systems which do meet the stress allowables of the code. This comparison is achieved by observation of rules used to locate deadweight and seismic supports and rules used to determine which supports must be non-rigid in order to assure sufficient flexibility for thermal expansion and anchor movements.

The examination of the piping proceeded as follows: Isometric sketches of the piping were made and consecutive sections called half spans were examined in accordance with the rules outlined in the Standard. Tables A-1 and A-2 show the span lengths and spani loads for piping of various diameters. Valves contained in Table A-2 were calculated for the $.35 \mathrm{~g}$ seismic event at the LOFT site. Once deadweight and seismic supports were located, these supports were checked for stresses imposed by anchor movement and pipe thermal expansion using the rules outlined in the Standard in conjunction with Tables A-3 and A-4. In cases where the operating temperature was less than $100^{\circ} \mathrm{F}$, anchor movements were ignored. Since the required offsets for thermal growth were given for a temperature of $200^{\circ} \mathrm{F}$, instances where the actual offset was not sufficient were noted, but in most cases were considered adequate, if the actual offset was close: to the required offset. Work sheets were used to document the employed procedure and are available upon request from the Applied Mechanics branch. 
After analysiss for deadweight, seismic and thermal loadings was completed, another on-site "walk-through" was made to verify the validity of new support configuration. In areas where wall penetrations had been previously ignored, or where nearby anchor points or hangers gave adequate support, installations indicated by the Standard were removed. During this "walk-through" it was found that some lines attached to line 1"-PC-57-VA (see sketch No. 5) were not adequately supported. An analysis of these lines should be made.

The results of this review form the remainder of this report and consist of Table I, Index of Examined Lines, the piping sketches indicating additional hanger locations; Table II, which lists the hangers, their directions and their imposed loads; and an Appendix which contains a copy of the Tables and rules provided by the Applied Mechanics Branch Piping Design Standard. The imposed loads were determined by consideration of all seismic loadings between adjacent hangers plus all deadweight loadings for all hangers acting in the vertical direction. Table I also suggests types of hangers to be used. For the most part, U-bolts are recommended because at many locations a two-directional restraint is indicated. In areas where a $U$-bolt is indicated for a onedirectional restraint, loadings in the other direction were checked and, unless noted, may be considered to be the same as the listed valve. When bolting the U-bolt to the pipe, use two nuts on each leg to prevent deformation of the pipe or the support plate during assembly.

The following symbols are used on the isometrics:

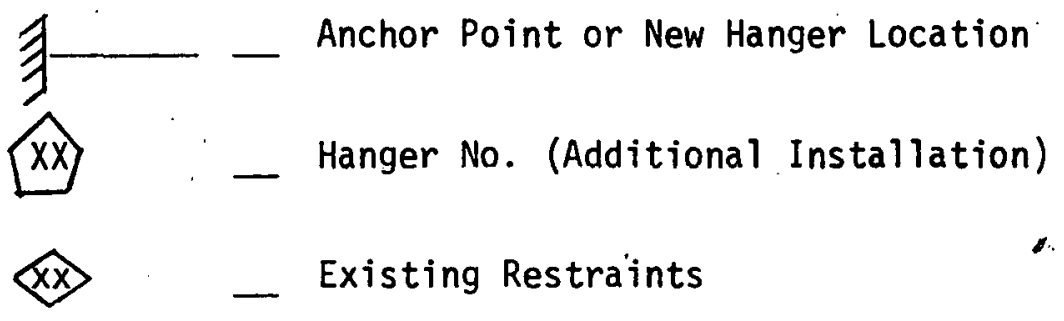


The reanalysis of the piping shown on ISO \#1 was performed analytically using the SAPP, SAPSP10, and INEL-PIPE II computer programs. The piping model and configuration for revised supports for this system as shown on this sketch designates ISO \#I modified. The basis for this analysis is given in the following paragraph:

The piping system was assumed to be subject to the following loading conditions:

1. Operating temperature $200^{\circ} \mathrm{F}$

2. Operating pressure $600 \mathrm{psig}$

3. Relief valve operation-loads as determined by the Thermal Analysis Branch

4. Seismic loading-Safe Shutdown Earthquake static equivalent - 2 cases

(a) $1.13 \mathrm{~g}$ horizontal component ( $x$ )

$.75 \mathrm{~g}$ vertical component $(z)$

(b) $1.13 \mathrm{~g}$ horizontal component (y) $.75 \mathrm{~g}$ horizontal component $(\mathrm{z})$

5. Valve data

CV valves - 35 pounds at assumed mass center of valve and operator 5 inches above pipe center line

Relief valves - 24 pounds at assuad mass center on vertical axis

The following tapes were created:

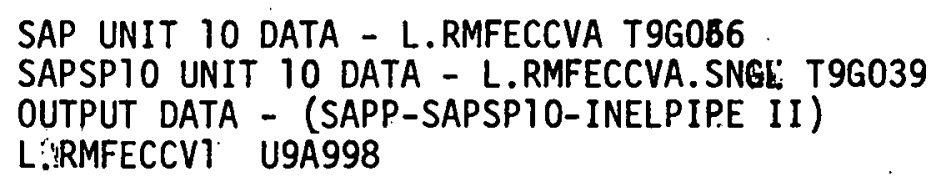

Results of the run show that all stresses satisfy allowable stress limits for Class II or III pipiny. Microfiche copies of the SAPSPIO and INEL-PIPE II programs as well as output is included as appendices to this report. Maximum loads at supports are given in the following table.

Support No.

(Boundary Element)

1 (Reaction at Wall)

Load $1 b^{(a)}$

2 (Reaction at Wall)

$25,-31$

3

$137,-105$

$131,-110$

4

$-15,-177$ 
Support No. (Boundary Element)

5

6 (b)

7

8

9

10

11

12

13

14
Load $1 b^{(a)}$

$51,-38$

$41,-99$.

$62,-416$

$78,-35$

४ T22,52

$6,-1-27$

$50,-497$

$129,-77$.

$256,-79$

$6,-41$

(a) A positive load is a load due to a pipe displacement in the positive coordinated direction. Support numbers in this table and the associated loads refer to the boundary element number designation of the pipe restraints in the referenced analys is and correspond to the designation shown on the isometric, sketch by the small numbers such as "B.E.I". These numbers are distinct from the hanger numbers in Táble II.

(b) Support pairs 6,$7 ; 8,9 ; 10,11,12, \& 13$ simulate $U$ bolts at the restraint locations. These $U$ bolts must be installed so as to permit axial movement of the pipe due to thermal expansion.

One run was also made to determine whether axial restraint at the valve locations was permissible. This run gave an overstress condition at one elbow location. It was therefore concluded that some freedom of axial. movement was required. The tapes associated with this run are:

$$
\text { SAP UNIT } 10 \text { DATA L.RMFECCVA }
$$$$
\text { T93577 }
$$

SAPSPT10 UNIT 10 DATA L.RMFECCVA.SNGL

OUTPUT

3-2-77

L.RMFECCV2

U9I422 
T A B L E I

INDEX OF EXAMINED LINES

Line No.

$1 "-E C C-134-A$

$1 "-E C C D-17-V B$

$1 / 2^{\prime \prime}-E C C D-21-V D$

$1 / 2^{\prime \prime}-E C C D-22-V F$

$1 "-E C C D-25-V F$

$1 "-E C C D-27-V F$

I"-ECCD-29-VB

1"-ECCD-31-VG

1"-ECCD-32-VG

$1 "-E C C D-53-V B$

$1 "-E C C D-54-V B$

$1 "-E C C D-55-V B$

1"-ECCD-57-VB

$1 "-E C C D-58-V B$

$1 "-E C C D-59-V B$

$1 "-E C C D-60-V B$

$1 "-E C C D-65-V B$

$1 "-E C C D-114-V F$

1 "!-ECCD-115-VF

$7 "-E C C V-6-A$

1"-ECCV-7-A

3"- ECCV-10-A

2"-ECCV-10-A

2"-ECCV-11-A

1"- ECCV - 21-VB

$1 "-E C C V-22-V B$

]"-ECCV-23-VB

j"-ECCV-24-VB

$1 / 2^{\prime \prime}-E C C V-116-V B$

$1 / 2^{\prime \prime}-E C C V-117-V F$

$1 / 2^{\prime \prime}-E C C V-118-V B$

$1 / 2^{\prime \prime}-E C C V-119-V F$

$1 / 2 "$ - ECCV-121-VF

1"-ECCV-123-VF

$1 / 2 "-E C C V-123-V F$

$3 / 4 "-C-271-E$

1"-PC-54-VD

$1 / 2 "-P C-55-V A$

3/4"-PC-56-VA

j"-PC-57-VA

$1 / 2$ " - PRD-249-E
Isometric No. 


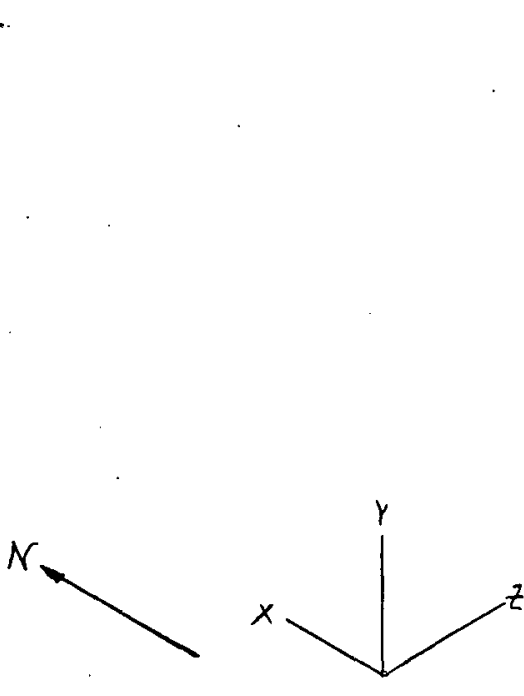

o
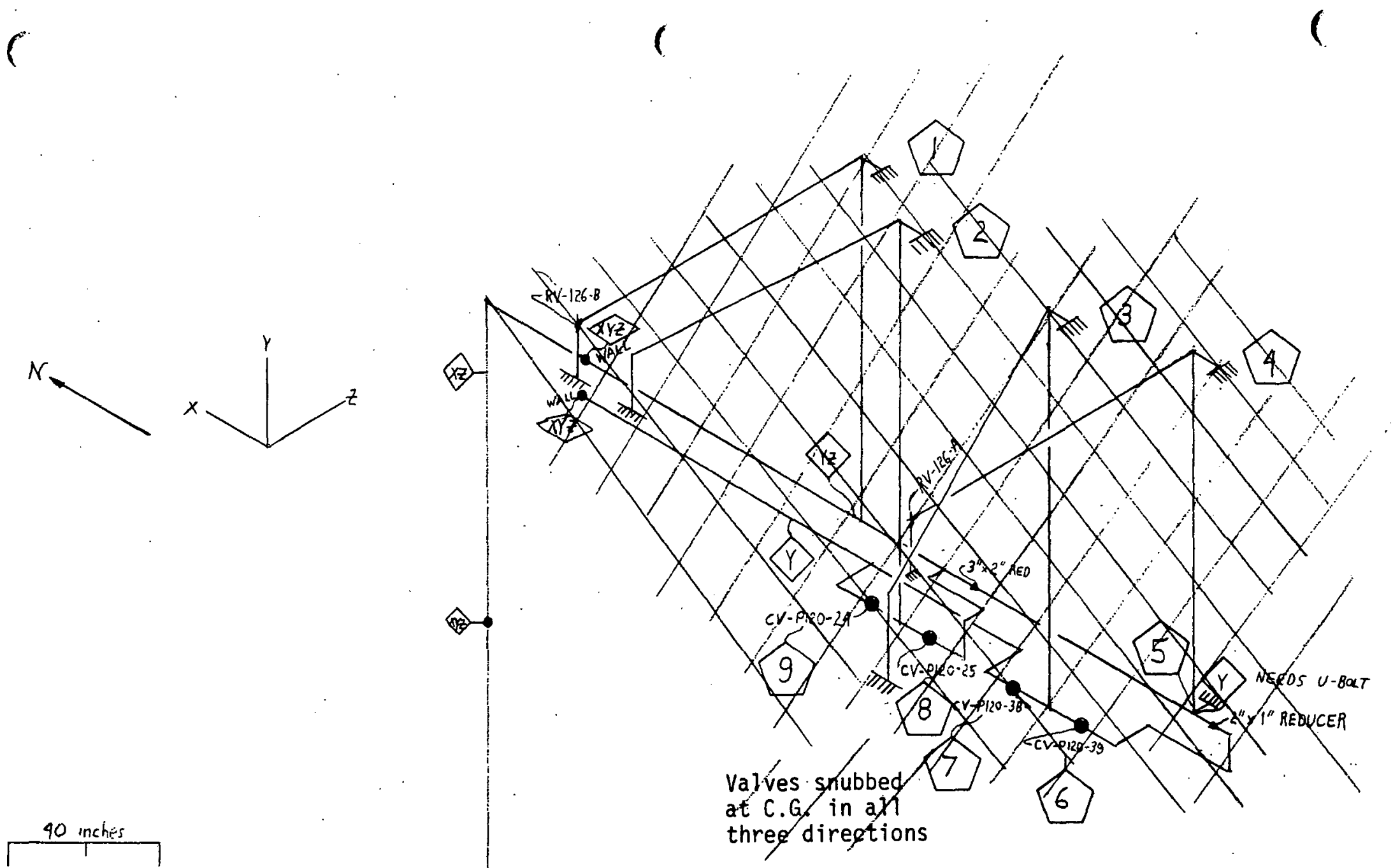

\section{Note:}

Restraint pairs A\&B

fail thermal analysis in $X$. Considered negligible for operating temperature $\leq 1000 \mathrm{~F}$.

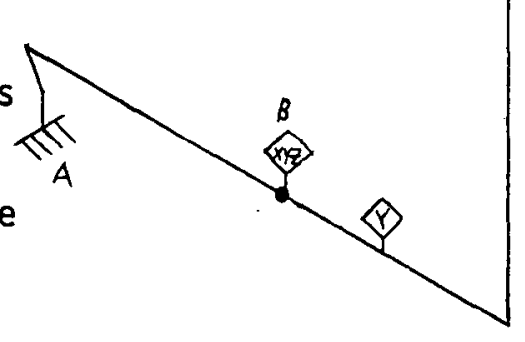

$$
\begin{aligned}
& 1^{\prime \prime}-E C C V-6-A \\
& 1^{\prime \prime}-E C C V-21-V B \\
& 2^{\prime \prime}-E C C V-10-A \\
& 1^{\prime \prime}-E C C V-7-A \\
& 1^{\prime \prime}-E C C V-23-V B \\
& 1^{\prime \prime}-E C C V-24-V B \\
& 2^{\prime \prime}-E C C V-11-A \\
& 3^{\prime \prime}-E C C V-10-A
\end{aligned}
$$




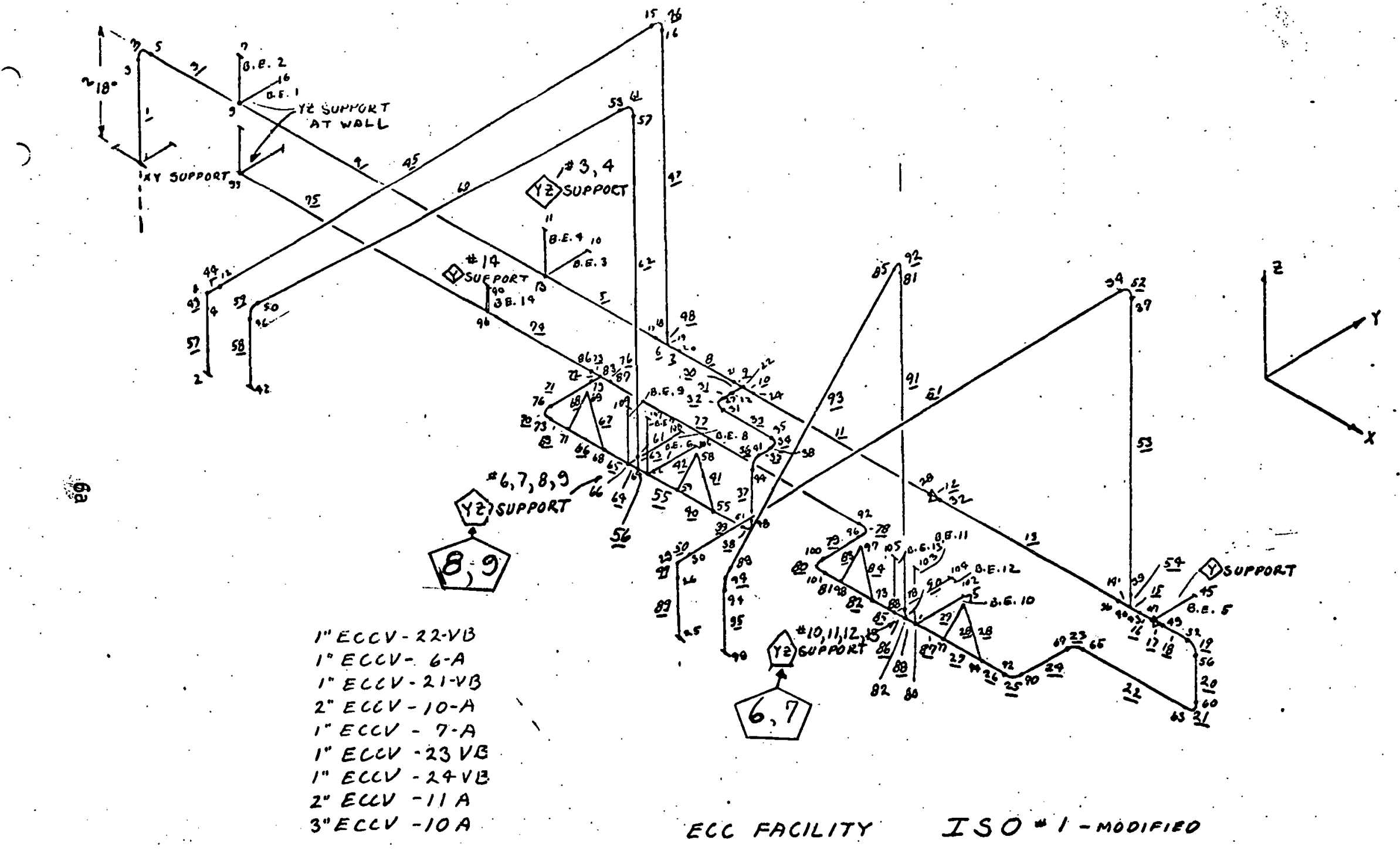




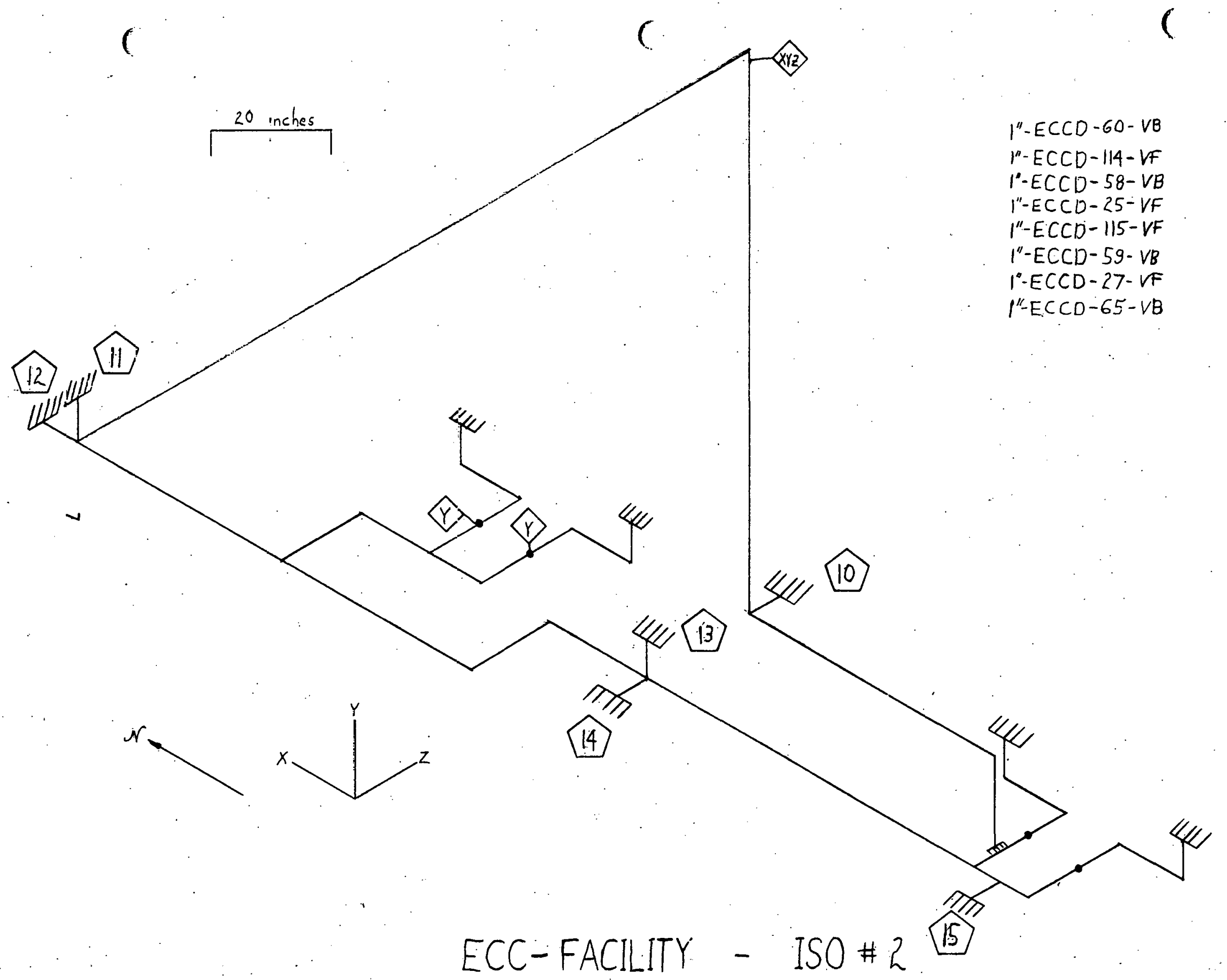




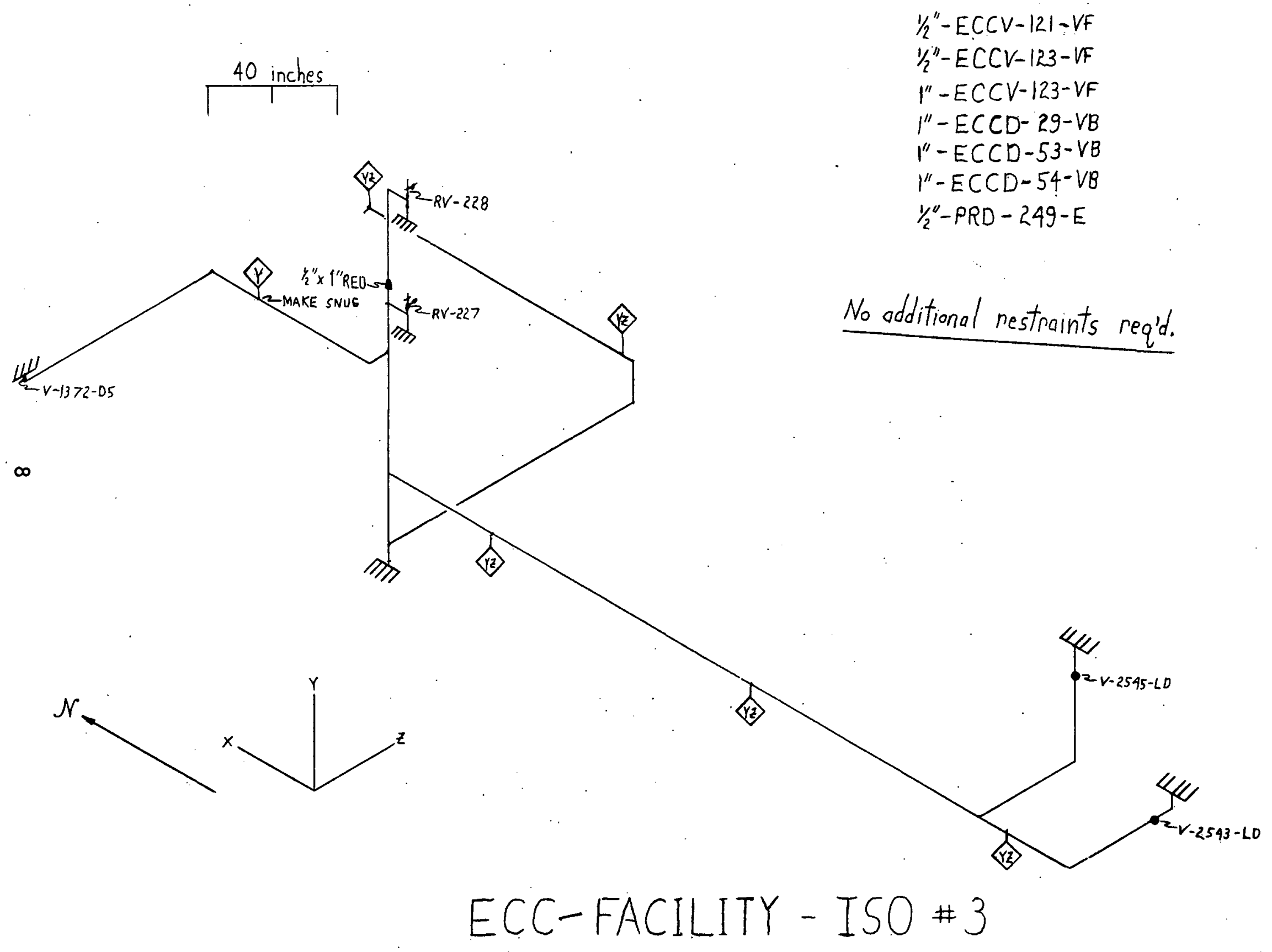




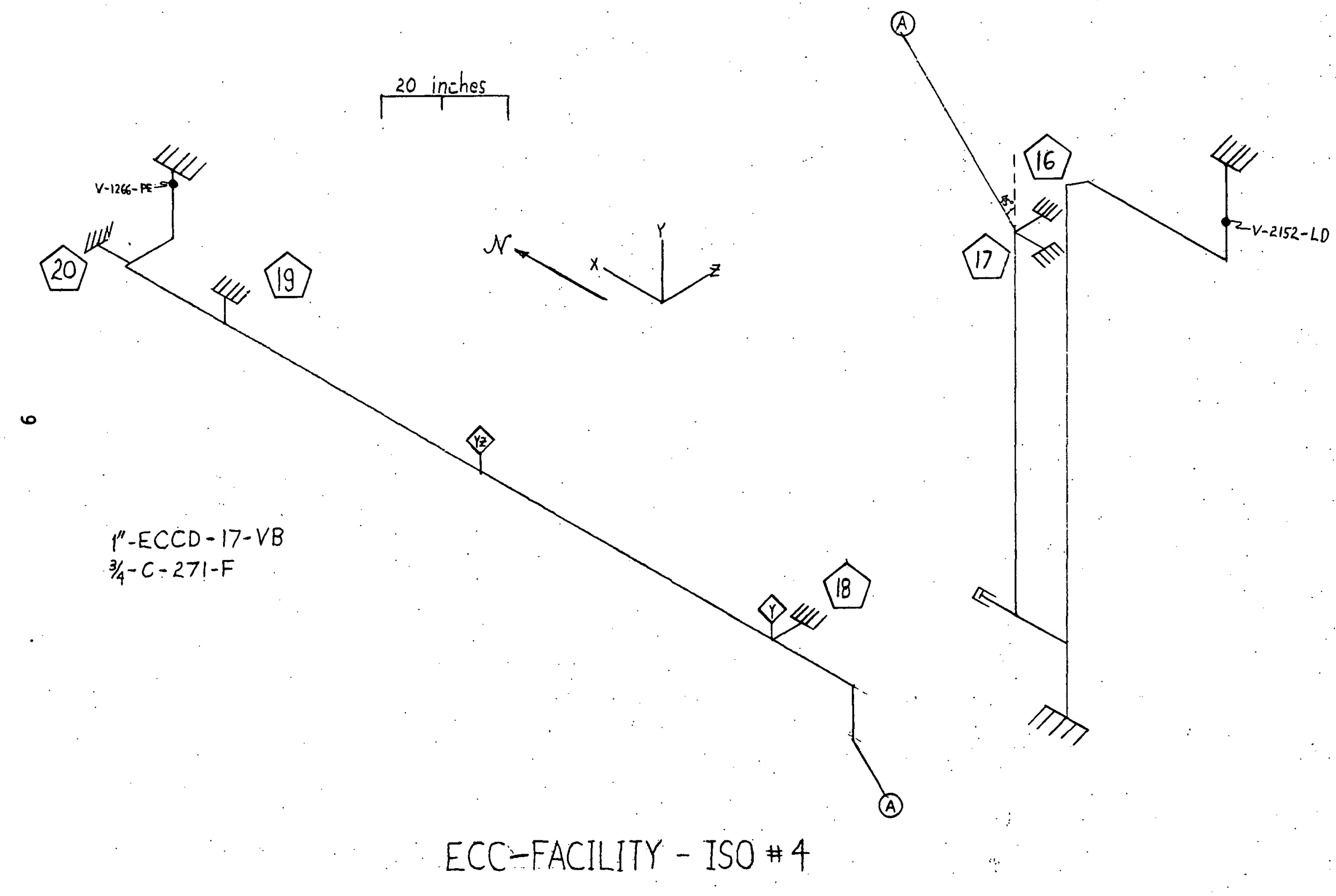


$\overrightarrow{0}$
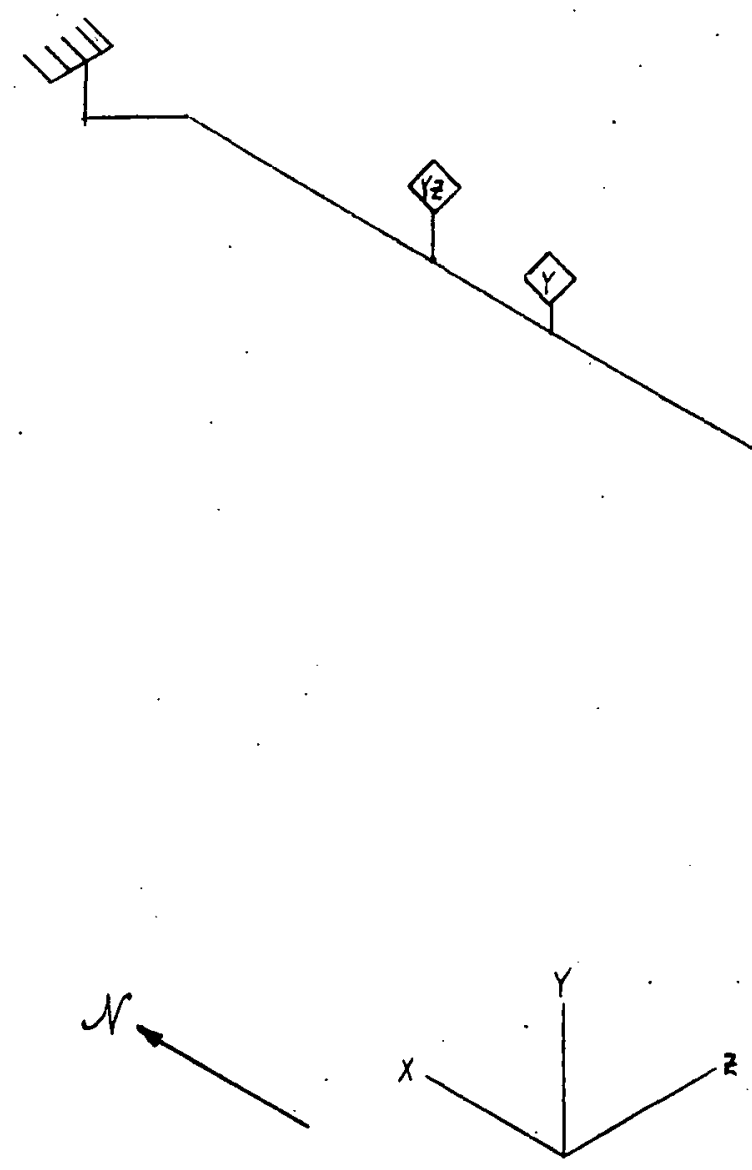

$$
\begin{aligned}
& 1 / 2 "-P C-55-V A \\
& 3 / 4^{\prime \prime}-P C-56-V A \\
& 1 "-P C-57-V A \text { (Partial) }
\end{aligned}
$$

Note: Branch 1 ines from 1"-PC-57-VA not analyzed. supports are needed.

$$
\text { ECO - FACILITY - ISO\# } 5
$$



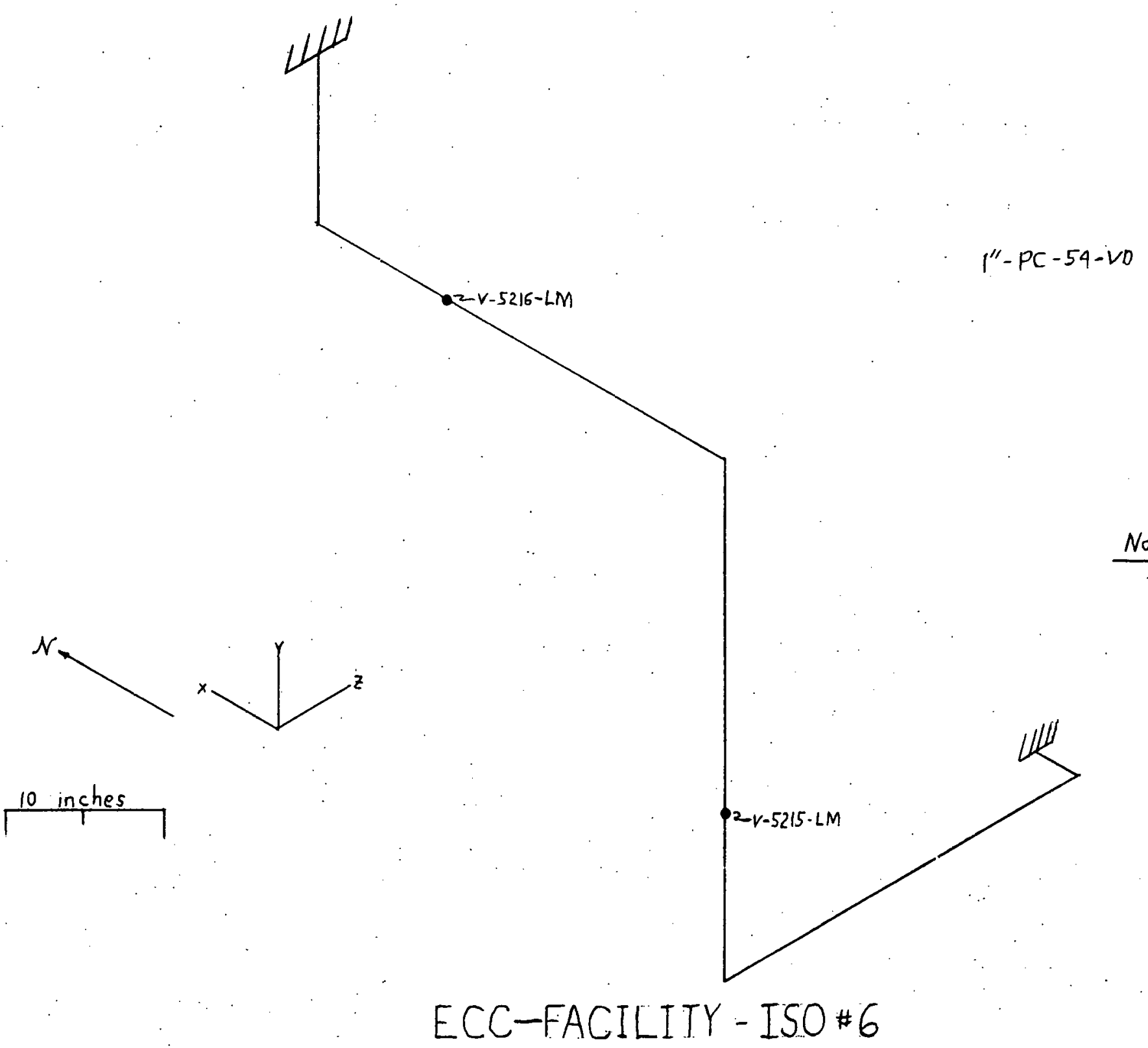

No instollotions requined,

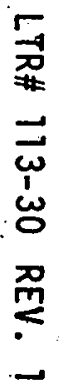




$$
I^{\prime \prime}-E C C-134-A
$$
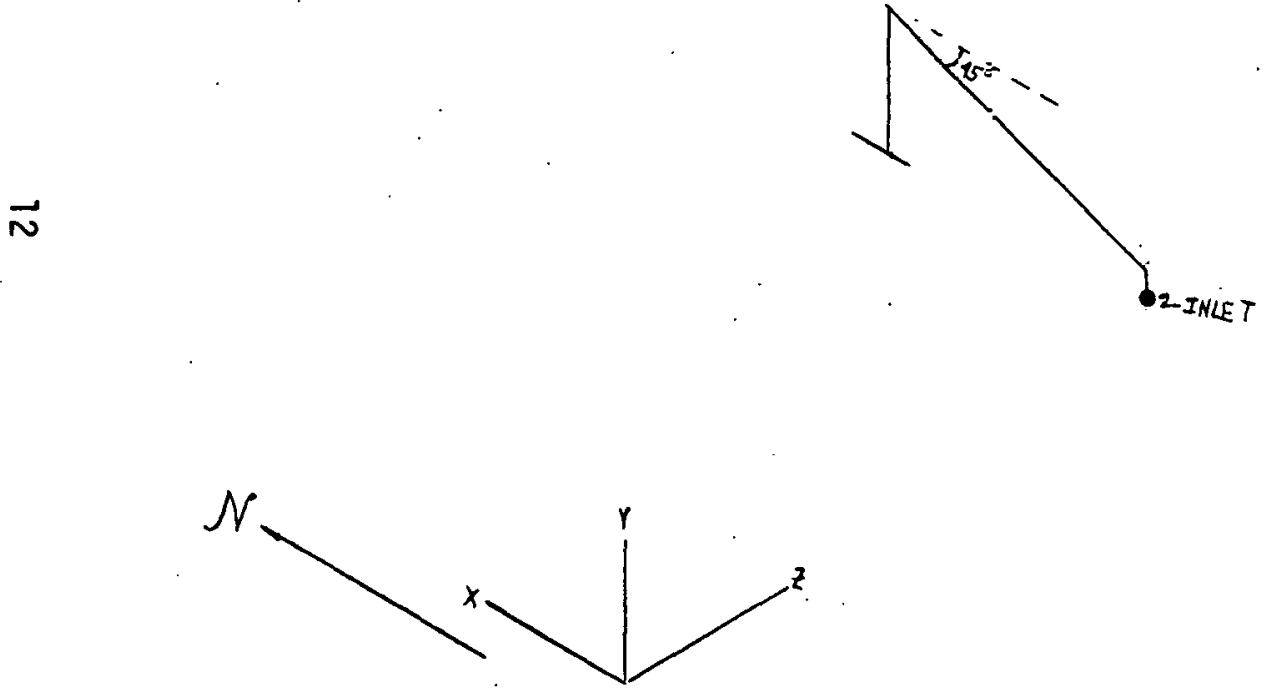

Note: Installation incomplete. Hangers may be required in all 3 directions just above inlet valve.

10 inches

$$
\text { ECC - FACILITY - ISO*7 }
$$


C

(

C

$I^{\prime}-E C C D-2 Z-V F$

$\vec{\omega}$

此

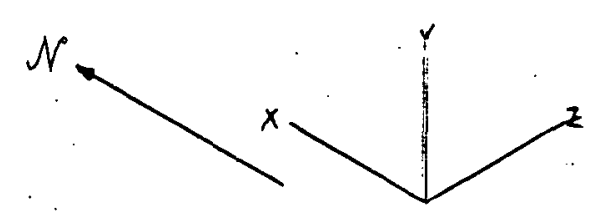

No hengens required.

10 inches

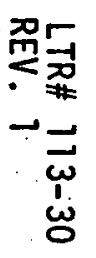

ECC-FACILITY - ISO 8 
$1^{\prime \prime}-$ ECCD-31-VG
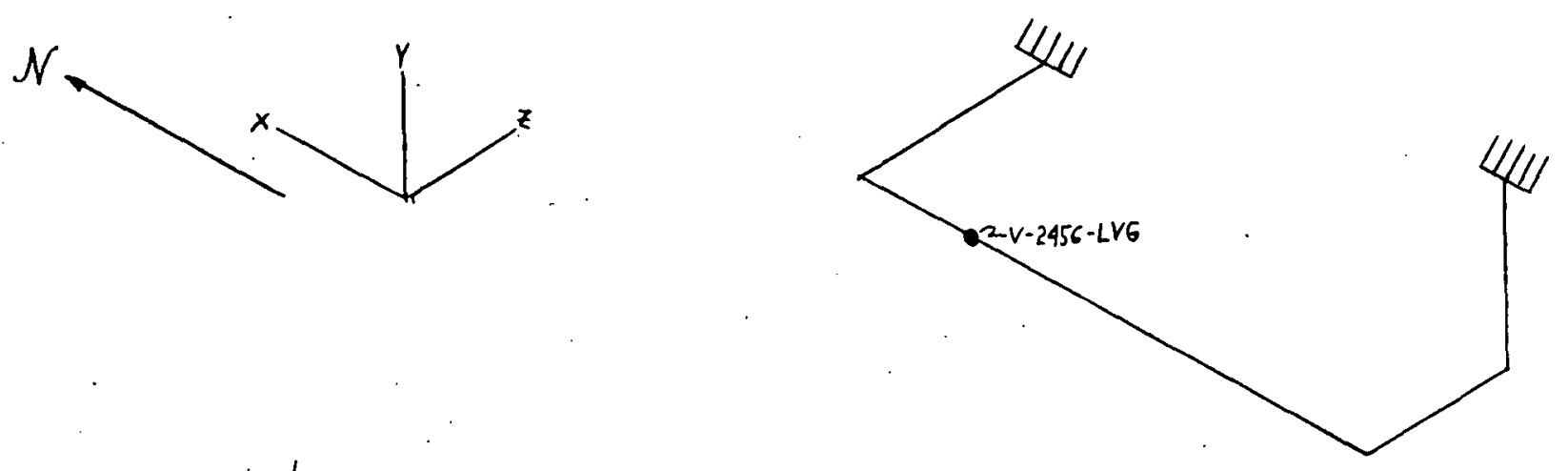

No hangens required

10 inches 
C

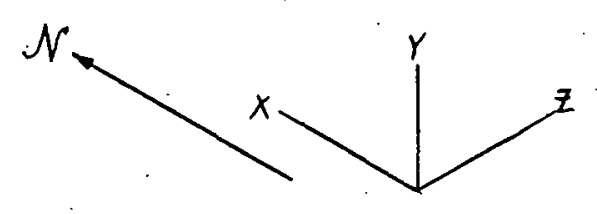

10 incines

जे

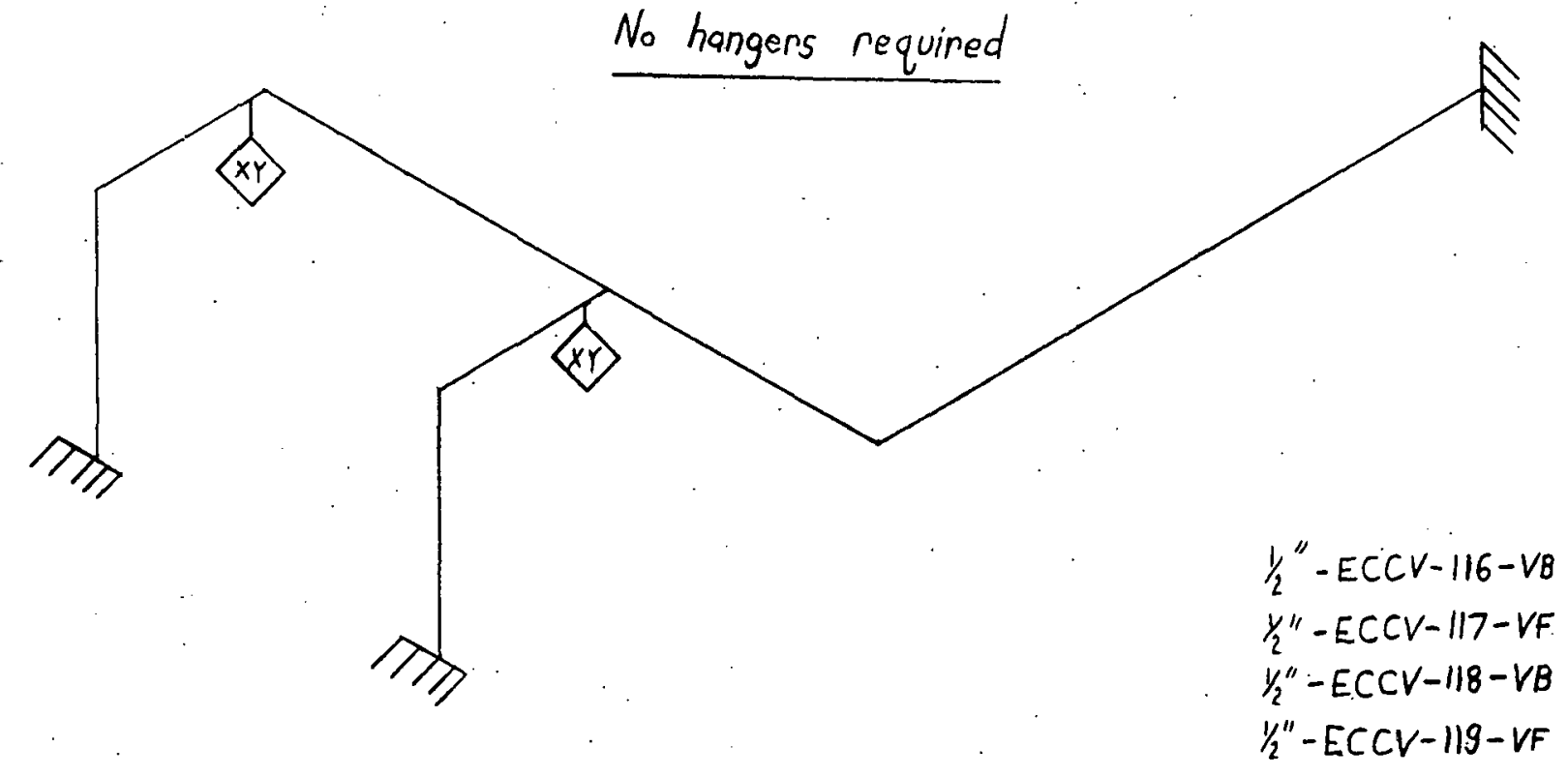

备

$$
\text { ECC-FACILITY - ISO } 10
$$


No hangers required.

Existing restraint fails thermal check in $x$-direction. Considered adequate for operating temperature of $150^{\circ} \mathrm{F}$.

$\vec{\sigma}$

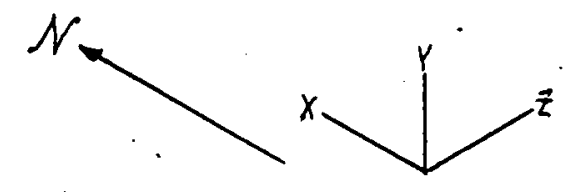

10 inches: $1^{\prime \prime}-E C C D-57 \cdot V B$

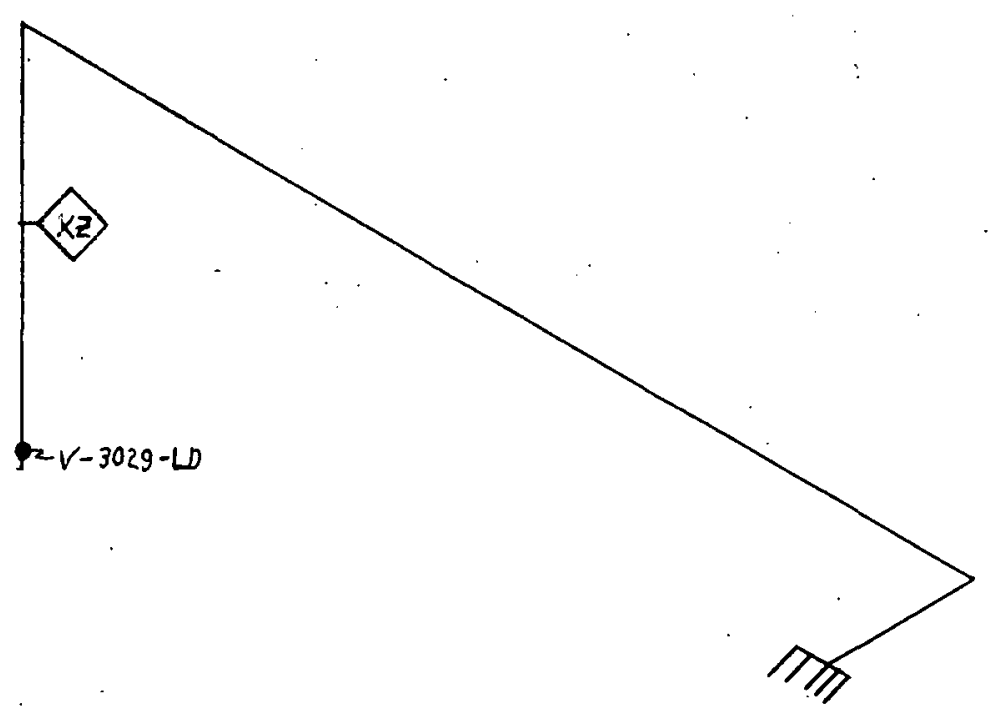

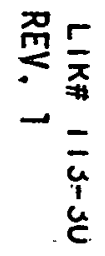




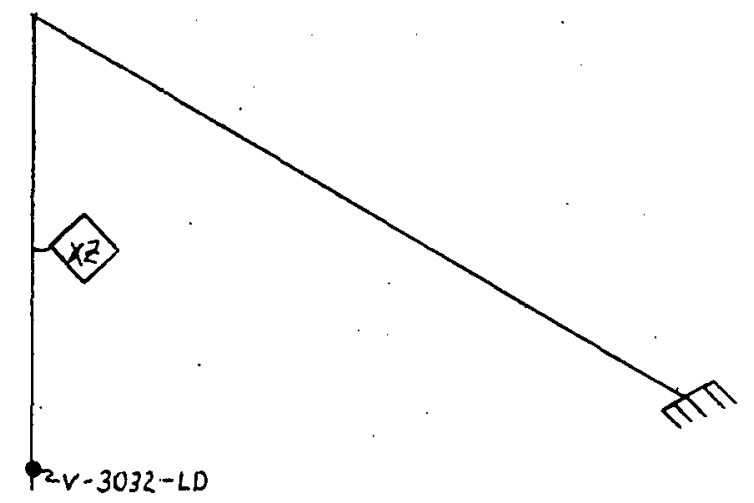

$\vec{\nabla}$ $1^{\prime \prime}-E C C D-55-V B$

No hangens required.

Existing restraint fails thermal check in $x$-direction. Considered adequate for operating temperature of $150^{\circ} \mathrm{F}$.
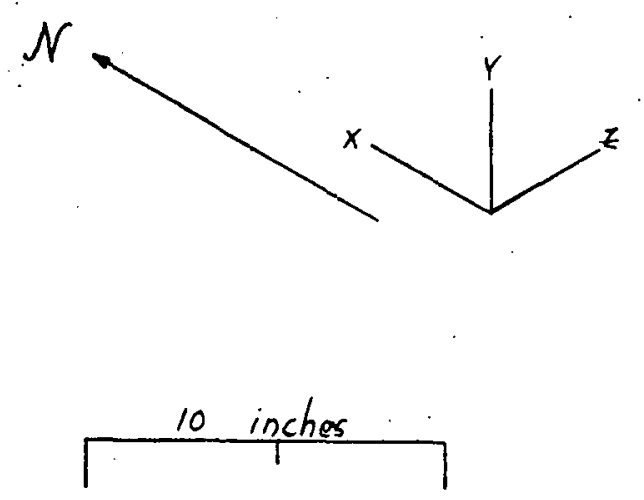


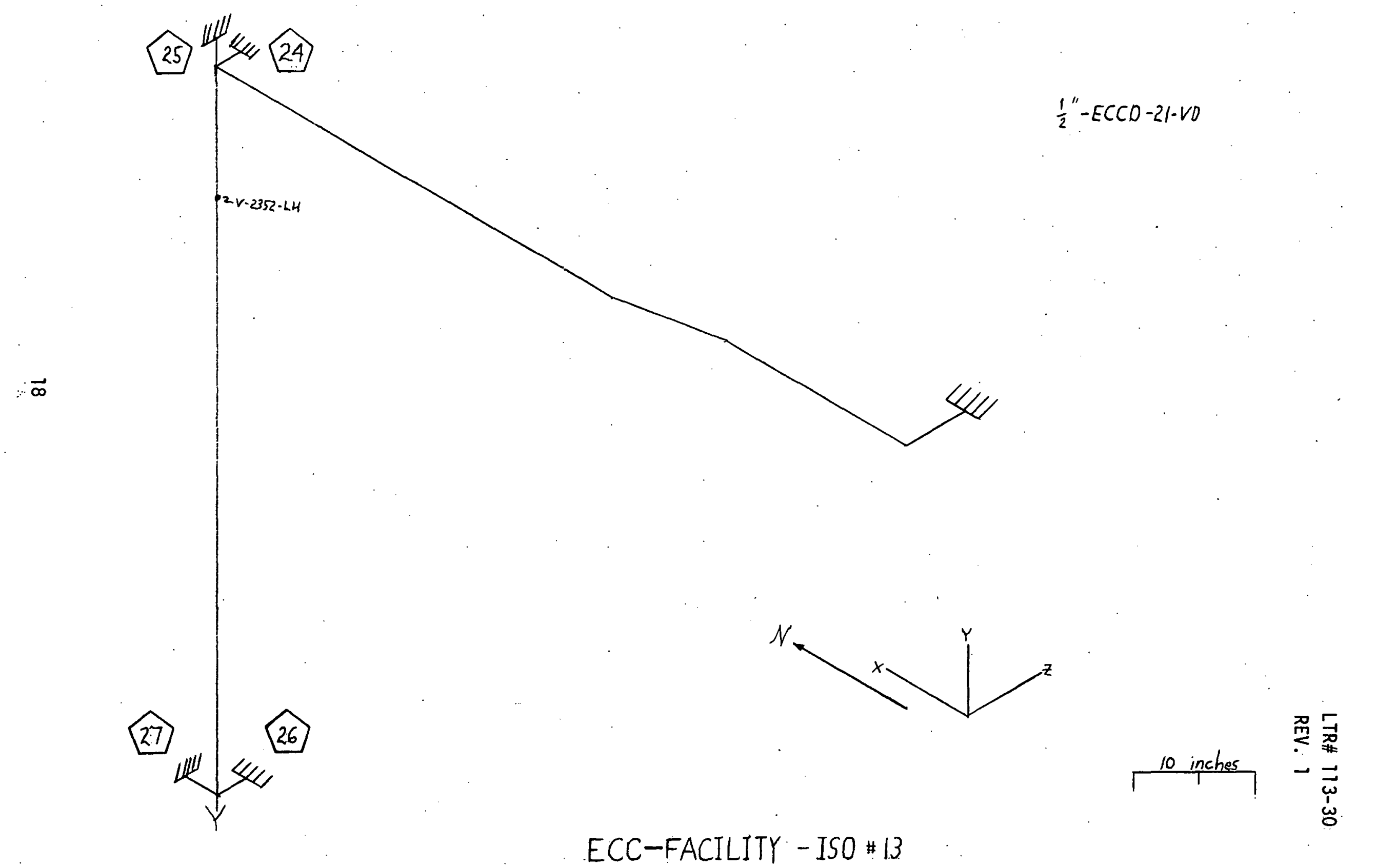


C

c

C

$\overrightarrow{0}$

28
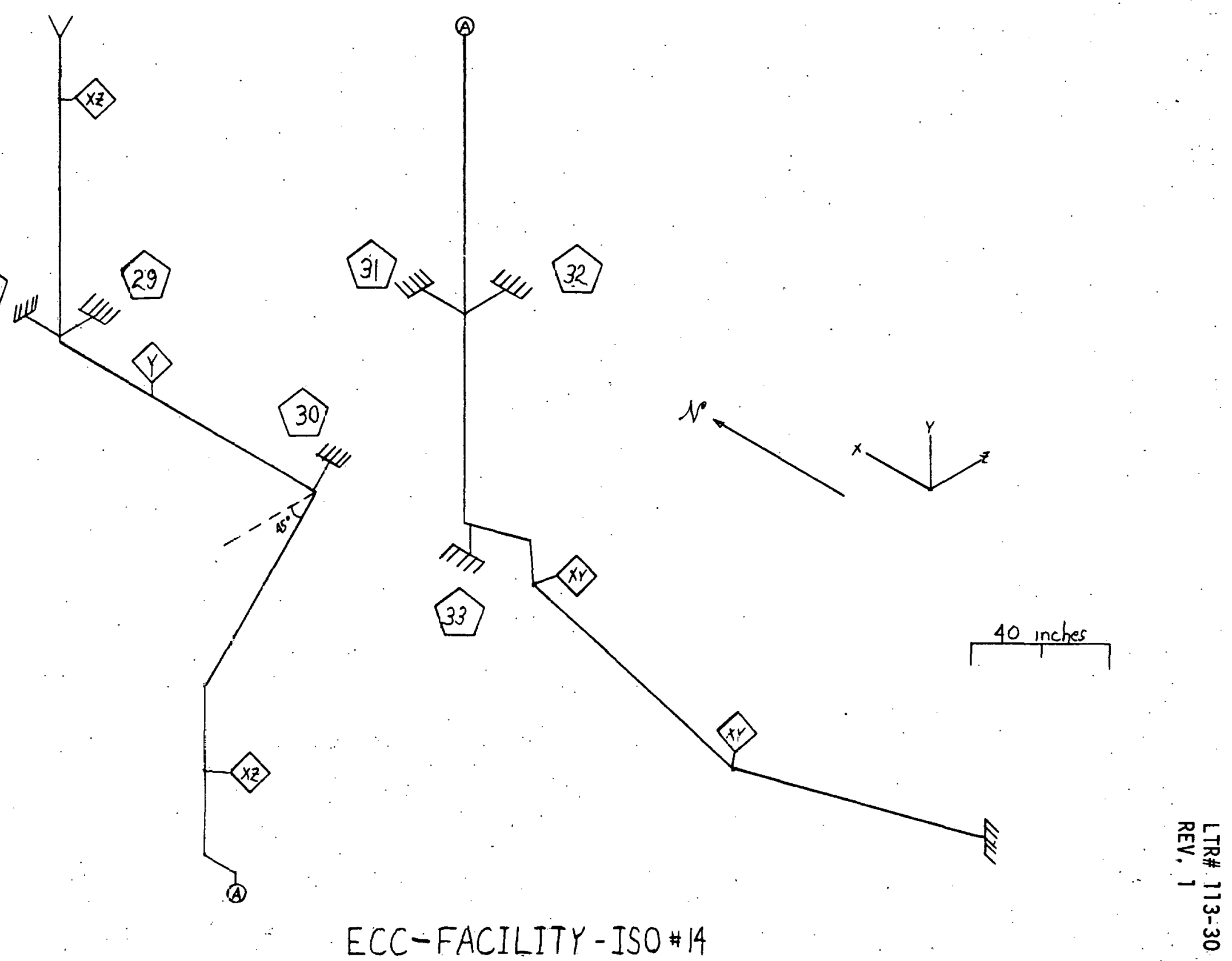

$1^{\prime \prime}-E C C D-32$-VF 
T A B L E II

LOFT EMERGENCY CORE COOLANT FACILITY PIPING - RECOMMENDED INSTALLATIONS

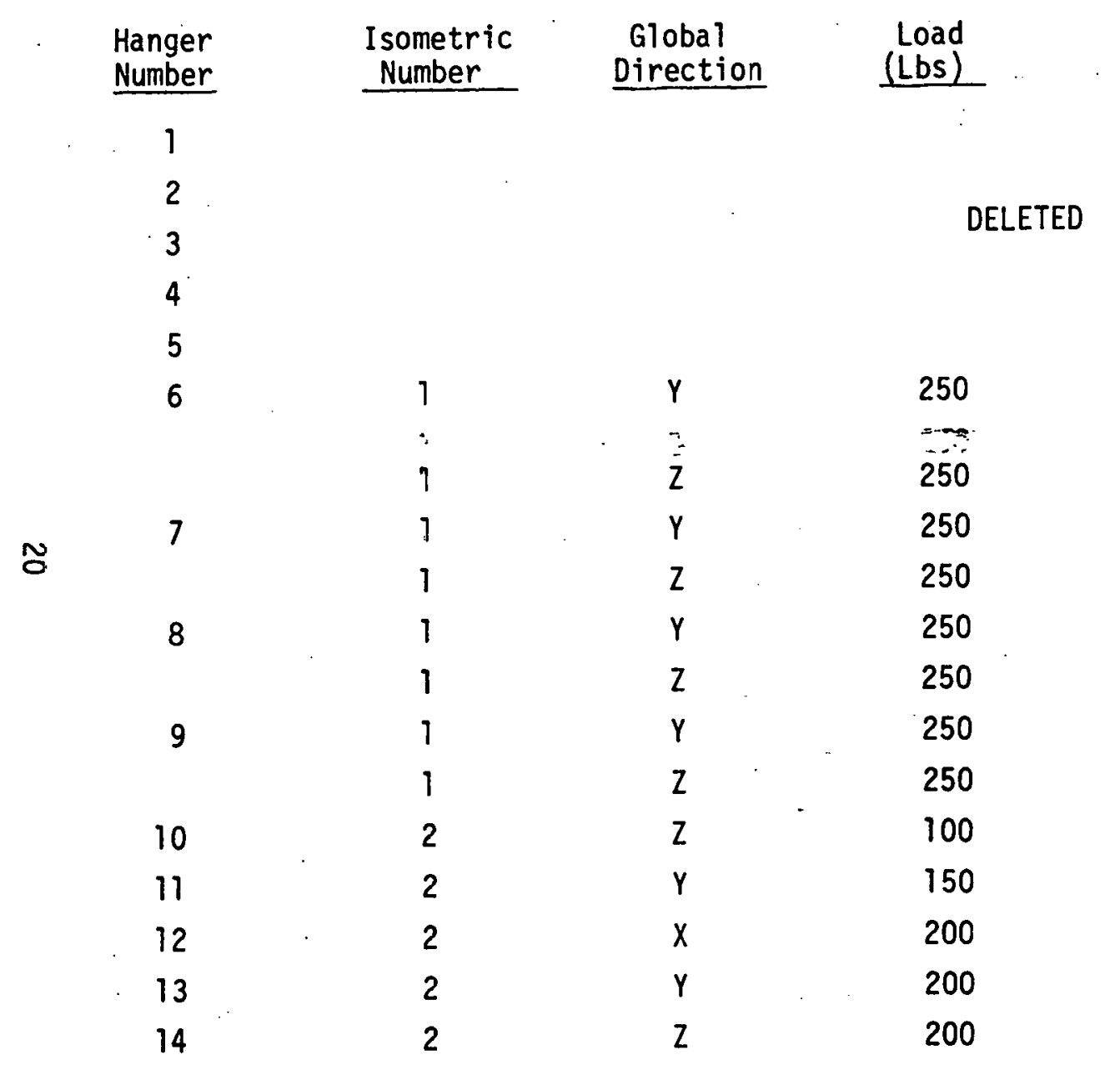

Type and Location

Existing U-Bolt Modified to Prevent Axial Movement of Pipe within U-Bolt

\begin{tabular}{|c|c|c|c|c|c|c|}
\hline 11 & " & "I & & "I & 11 & $"$ \\
\hline " & " & " & & " & '" & $"$ \\
\hline " & " & " & & " & " & " \\
\hline 11 & $"$ & $"$ & & " & " & " \\
\hline " & " & " & . & " & " & " \\
\hline "I & " & " & & " & "1 & " \\
\hline "I & $\|$ & 11 & & " & " & 11 \\
\hline
\end{tabular}

Rod Hanger Just South of Elbow U-Bolt Just East of Elbow U-Bolt Just East of Elbow $U$-Bolt 18 Inches South of Elbow U-Bolt 18 Inches South of Elbow
5.

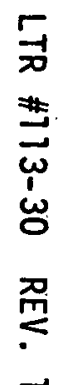




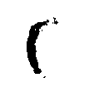

T A B L E II (continued)

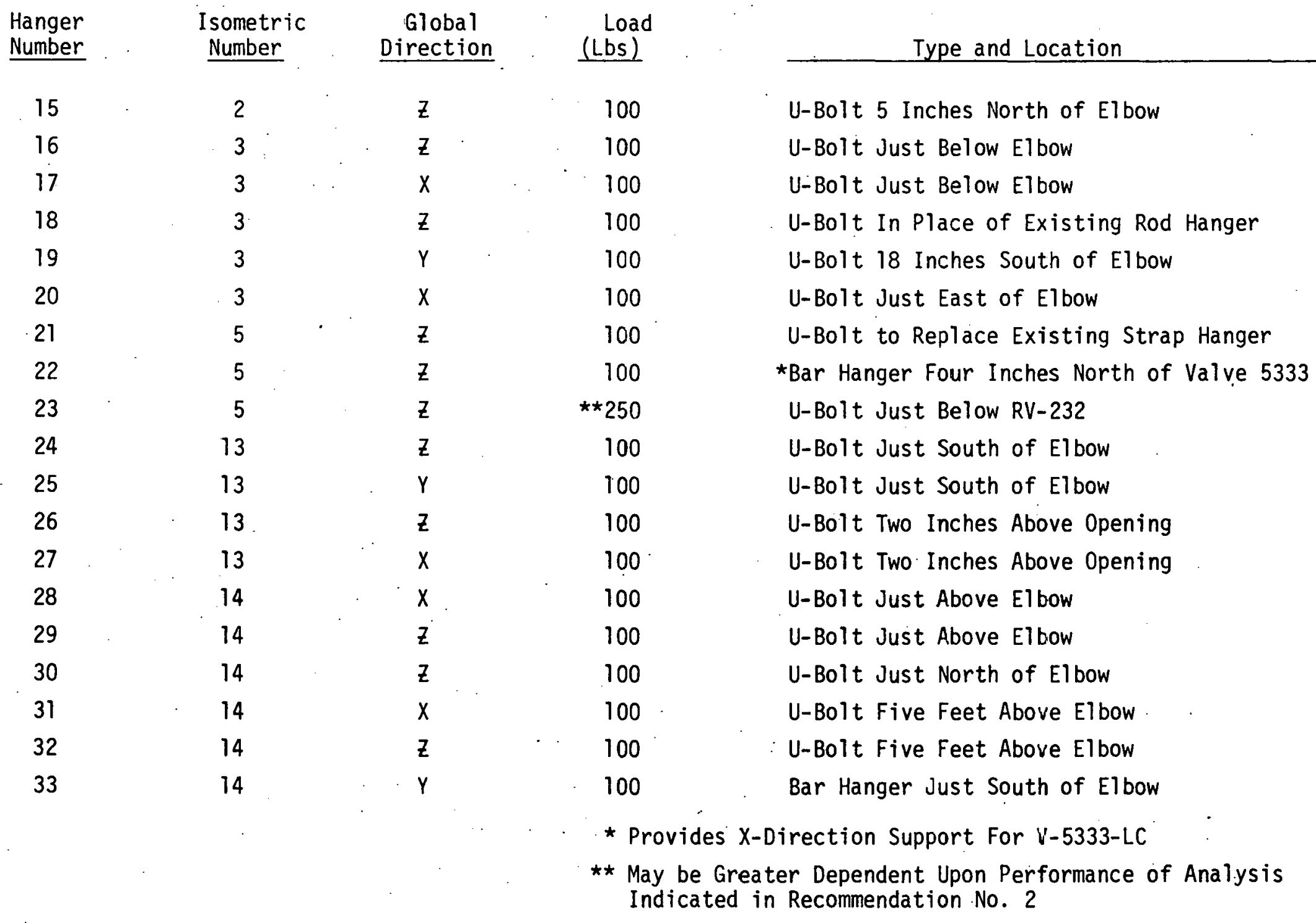




\author{
A P P ENDIX A \\ RULES AND TABLES PROVIDED FROM \\ APPLIED MECHANICS BRANCH \\ PIPING DESIGN STANDARD
}

(Ltr 10-21) 


\section{A.1. Rules for locating Weight Supports}

1. A half-span of plain pipe must have a vertical support at one end.

2. A half-span which includes an elbow must have a vertical support at both ends.

3. The length of a half-span which includes a concentrated weight of less than $10 \%$ of the normal span load (Table $B-1$ ) should not exceed $40 \%$ of the normal span length. It must have a vertical support on one side.

4. A half-span which includes a concentrated weight of from $10 \%$ to $40 \%$ of the normal span load must have a vertical support on both sides.

5. The length of a half-span which includes a concentrated weight of more thian $40 \%$ but less than $250 \%$ of the normal span load should not exceed $10 \%$ of the normal span length and should have a. vertical support on both sides. This length does not include the actual length of the concentrated weight.

6. A concentrated. weight which exceeds $250 \%$ of the normal span load should be supported directly rather than by the piping to which it is attached.

7. The length of a half-span with one free end should not exceed $50 \%$ of the normal span length.

8. A half-span with a concentrated weight should not have a free end.

9. Supports not required by these rilles should not be used. 
TABLE A-1

RECOMYENDED SPNNS FOR DEND WEIGIT SUPPORTS.

NOS.

WATER-FILTED

GAS-FILUED

ROD

DIXY.

SPAN* LOAD (LB)

SPAN* LDAD (LB)

DIAY.

i. $/ 2$

$5^{\prime}-5^{\prime \prime} . \quad 12$

$6^{\prime}-10^{\prime \prime} \quad 10$

$\begin{array}{lll}40 & 5^{\prime}-5 " & 12 \\ 80 & 6^{\prime}-6^{\prime \prime} & 12\end{array}$

12.

$6^{\prime}-10^{\prime \prime} \quad 12$

260

$6^{\prime}-6^{\prime \prime}$

$0^{\prime \prime}-7 "$

14

$3 / 8$

$3 / 4$

40

$7 \cdot-7 "$

16

$8^{\prime}-4^{\prime \prime} \quad 16$

$8^{\prime}-4^{\prime \prime} \quad 18$

$8^{\prime}-1$ '

22

$3 / 8$

160

7'-10" 22

2

$\begin{array}{rrr}40 & 9^{\prime}-0^{\prime \prime} & 26 \\ 80 & 9^{\prime}-2^{\prime \prime} & 32 \\ 160 & 9^{\prime}-2^{\prime \prime} & 33\end{array}$

$9^{\prime}-10^{\prime \prime}$

24

32

$9^{\prime}-10^{\prime \prime} \quad 30$

$9^{\prime}-6$ "' 38

$3 / 8$

$1-1 / 4$.

$\begin{array}{lll}40 & 10^{\prime}-5^{\prime \prime} & 42 \\ 80 & 10^{\prime}-9^{\prime \prime} & 50\end{array}$

42

$11 \cdot-7 " \cdot 38$

50

$1 \cdot 1^{\prime}-6^{\prime \prime}$

11 ' 5"

45

5.5

$1-1 / 2$

40

$11^{\prime}-4^{\prime \prime}$

52

$12^{\prime}-10^{\prime \prime}: 48$

$8011^{\prime}-3^{\prime \prime}$

64

80

$12^{\prime}-10^{\prime \prime}$

58

160 1.'-10".

$12^{\prime}-5^{\prime \prime}$.

70

2

$\begin{array}{rrr}4 i & 12^{\prime}-9^{\prime \prime} & 82 \\ 80 & 13^{\prime}-2^{\prime \prime} & 102 \\ 160 & 13^{\prime}-6^{\prime \prime} & 136\end{array}$

$2-x / 2$

40 14'-6"

$80.15^{\prime}-0^{\prime \prime}$

160

$15^{\prime}-1^{\prime \prime}$

138

168

202

14 ' -9 "

$14^{\prime}-9^{\prime \prime}$

$14 \cdot-4$ "

72

94

123

$3 / 8$

3

$\begin{array}{rrr}40 & 15^{\prime}-6^{\prime \prime} & 210 \\ 80 & 16^{\prime}-2 " & 248 \\ 160 & 16^{\prime}-7 " & 326\end{array}$

$$
3-1 / 2
$$

$\begin{array}{rrr}45 & 16^{\prime}-7 " & 272 \\ 80 & 17^{\prime}-5 " & 340 \\ \times \times 5 & 17^{\prime}-11 " & 520\end{array}$

$16^{\prime \prime}-9^{\prime \prime}$

120

$16^{\prime}-7^{\prime \prime} \quad 152$

$16^{\prime}-2^{\prime \prime} \quad 190$

$3 / 8$

$3 / 8$

.

$\times \times 5$

$27^{\prime}-11^{\prime \prime}$

520

$18:-1 " \quad 180$

$28^{\prime}-1 " 10^{\prime \prime} \quad 232$

$17^{\circ}-10^{\prime \prime} \quad 306$

$1 / 2$

4.8
326

$19^{\prime}-9^{\prime \prime}$

.

$19^{\prime}-9^{\prime \prime}$

302

$18^{\prime}-11^{\prime \prime} 49.5$

$5 / 8$

1

$\begin{array}{rrr}40 & 17^{\prime}-7^{\prime \prime} & 346 \\ 80 & 18^{\prime}-7^{\prime \prime} & 436 \\ 260 & 19^{\prime}-2^{\prime \prime} & 584\end{array}$

$21^{\prime}-2 " \quad 290$

$21^{\prime}-3^{\prime \prime} \quad 384$

$20^{\prime}-6^{\prime \prime} \quad 542$

\section{$5 / 8$}

*hine actual span should not execod the reconnended value by more than 1 Eoot. 


\section{A. 2. Rules for locating seismic supports}

1. A horizontal half-span must have a horizontal, lateral restraint at one end.

2. A vertical half-span must have two orthogonal, horizontal restraints at one end.

3. A half-span which includes a bend and lies in a vertical plane must be supported at both ends-a horizontal, lateral support at the horizontal end and two orthogonal. lateral supports on the vertical end. (see rule 14).

4. A straight, horizontal section of pipe which is less than $4 / 10$ of the normal span in length requires no horizontal restraints. It is treated as a concentrated

- weight in its axial direction.

5. $\lambda$ horizontal section of pipe whose length exceeds $4 / 10$ of the normal span must be restrained along its axis.

6. A half-span which contains a concentrated weight of less than $10 \%$ of the normal seismic-span weight should not exceed $40 \%$ of the normal-span length. It should be supported on one side with horizontal restraints.

7. A half-span which includes a concentrated weight of from $10 \%$ to $10 \%$ of the normal seismic-span weight must be supported on both ends with horizontal restraints.

8. The length of a half-span which includes a concentrated weight of more than $40 \%$ but less than $250 \%$ of the normal seismic-span weight should not exceed $10 \%$ of the normal span. (exclusive of the actual length of the concentrated weight). This half-span should be supported on both ends by horizontal supports.

9. A concentrated weight wich exceeds $250 \%$ of the normal seismic-span weight should be supported directly, rather than by the piping to which it is attached. Horizontal support is required at the center of gravity. 


\section{A.2. Rules for locating scismic supports (continued)}

10. In general, motor operators for valves should be restrained in three oxthogonal directions. For vertically mounted operators, only horizontal. lateral support is requirea.

1). A half-span with a concentrated wejght should not have a free end; horizontal, lateral support should be provided.

12. Supports not required by these rules should not be used.

13. If the distance between adjacent rigid hangers exceeds the normal seismic support span, vertical supports should be added between these rigid hangers.

34. As an alternative to rule 3 , a half-span which. includes an elbow may end at the elbow and be supported at a tangent point. 
TABLE A-2

\section{LOFT FACILITY PIPING}

Recommended Soans for Seismic Restraints

\begin{tabular}{|c|c|c|c|c|}
\hline $\begin{array}{c}\text { Nom. Dia. } \\
\text { (in.) }\end{array}$ & Sch. & $\begin{array}{l}\text { Span } \\
(f t)\end{array}$ & : & $\begin{array}{l}\text { Load } \\
\text { (1b) }\end{array}$ \\
\hline $1 / 2$ & 160 & 11 & & 8 \\
\hline $3 / 4$ & 160 & 12 & & 12 \\
\hline 1 & 160 & 1.4 & & 20 \\
\hline $1 .-1 / 4$ & 160 & 16 & & 26 \\
\hline . $1-1 / 2$ & 160 & 17 & & 44 \\
\hline 2 & 160 & $1 \dot{9}$ & & 70 \\
\hline $2-1 / 2$ & 160 & 21 & & 86 \\
\hline 3 & 160 & 23 & $\cdot$ & 175 \\
\hline $3-1 / 2$ & $X S^{\circ}$ & 24 & & 170 \\
\hline 4 & 160 & 26 & & 330 \\
\hline
\end{tabular}


3. Procciure for Thermal Support system Design

Dll equipment nozzles and header connections should be checked for movement in three (orthogonal) directions. The movement in each direction should be checked with Table D-1 to determine the minimum acceptable offset. The offset is the total length of pipe which is perpendicular to the component of nozzle movement and lies between the nozzle and the first restraint which acts in the direction of that component. If that minimim is not met, an expansion loop must be added or a restraint changed to non-rigid (spring or snubber). The thermal expansion workshect serves as documentation for this process:

After all nozzle movements have been accomodated, thermal expansion of the pipe must be examined. The following procedure is recommended and is to be documented on the thermal expansion worksheet.

1. Identify all adjacent pairs of paraljel rigjd restraints.

2. Find the total length of pipe between the restraints of each pair with the pipe axis parallel to the direction of restraint.

3. Use Table D-2 to determine the minjmum acceptable offset for this length of pipe.

4. Find the total length of pire between restraints with pipe. axis perpendicular to the direction of restraint.

5. Provide expansion loops if inessary or change supports to non-rigid types so that the value from 3 docs not cxceed the the value from 4. 
TABLE A-3

RECOMYENOED OEFSET NEAR NOZZLES

FITH EXPANSIOI MOUEMENTS*

DEELECTION (IN)

\begin{tabular}{|c|c|c|c|c|c|c|c|c|c|c|c|}
\hline & & $1 / 4$ & $1 / 2$ & $3 / 4$ & 1 & $11 / 4$ & $11 / 2$ & $13 / 4$ & 2 & $21 / 4$ & $21 / 2$ \\
\hline & $1 / 2$ & $3^{\prime}-11^{\prime}$ & $5 \cdot-6 "$ & $6^{\prime}-9^{\prime \prime}$ & $7 \cdot-9 "$ & $8^{\prime}-9^{\prime \prime}$ & $9 \cdot-6 \cdot$ & $10^{\prime}-3 "$. & $11 \cdot-0: 1$ & $21 \cdot-8^{\prime \prime}$ & $12 \cdot-4^{\circ}$ \\
\hline & $3 / 4$ & $4 \cdot-4 \prime$ & $6^{\prime}-2 \prime$ & $7 \cdot-6 "$ & $8^{\prime}-9^{\prime \prime}$ & $9^{\prime}-9^{\prime \prime}$ & $10^{\prime}-8^{\prime \prime}$ & $11^{\prime}-6^{\prime \prime}$. & $12^{\prime}-4^{\prime \prime}$ & $133^{\prime}-0 "$ & $33^{\prime}-9 "$ \\
\hline 1 & . & $4^{\prime}-10^{\prime \prime}$ & $6^{\prime}-11^{\prime \prime}$ & $8^{\prime}-5^{\prime \prime}$ & $9^{\prime}-9^{\prime \prime}$ & $10^{\prime}-11^{\prime \prime}$ & $11^{\prime}-11 "$ & $12^{\prime}-11^{\prime \prime}$ & $13^{\prime}-9^{\prime \prime}$ & $14^{\prime}-7^{\prime \prime}$ & $15^{\prime}-5^{\prime \prime}$ \\
\hline 1 & $1 / 4$ & $5^{\prime}-6^{\prime \prime}$ & $7^{\prime}-9 \cdot$ & $9 !-6 "$ & $10^{\circ}-11 "$ & $12^{\prime}-3^{\prime \prime}$ & $\begin{array}{c}13^{\prime}-5^{\prime \prime} \\
1\end{array}$ & $14^{\prime}-6 "$ & $15^{\prime}-6^{\prime \prime}$ & $16^{\prime}-5^{\prime \prime}$ & $27 \cdot-4 \cdot$ \\
\hline 1 & $1 / 2$ & $5^{\prime}-10^{\prime \prime}$ & $8^{\prime}-3 \cdot$ & $10^{\prime}-2^{\prime \prime}$ & $12 \cdot-9 "$ & $23^{\prime}-2^{\prime \prime}$ & $14^{\prime}-4^{\prime \prime}$ & $15^{\prime}-5^{\prime \prime}$ & $16^{\prime}-\varepsilon^{\prime \prime}$ & $17^{\prime}-6^{\prime \prime}$ & $13 \cdot 6 "$ \\
\hline 2 & & $5 \cdot-6 "$ & $9^{\prime}-3^{\prime \prime}$ & $11^{\prime}-4^{\prime \prime}$ & $13^{\prime}-1^{\prime \prime}$ & $14^{\prime}-7^{\prime \prime}$ & $16^{\circ}-0^{\prime \prime}$ & $17^{\prime}-4^{\prime \prime}$ & $18^{\prime}-6^{\prime \prime}$ & $19^{\circ}-7^{\prime \prime}$ & $20 \cdot-6 "$ \\
\hline 2 & $1 / 2$ & $7^{\prime}-2^{\prime \prime}$ & $20^{\prime}-2^{\prime \prime}$ & $12^{\prime}-6^{\prime \prime}$ & $14^{\prime}-4^{\prime \prime}$ & $16^{\prime}-1 "$. & $=\begin{array}{c}17^{\prime}-8^{\prime \prime} \\
1\end{array}$ & $13^{\prime}-0^{\prime \prime}$ & $20^{\prime}-4 "$ & $21 \cdot-7 \cdot$ & $22^{\prime}-7^{\prime \prime}$ \\
\hline 3 & & $7 \cdot-11 "$ & $1 L^{\prime}-3 "$ & $13^{\prime}-9 "$ & $15^{\prime}-10^{\prime \prime}$ & $17 \cdot-9 "$ & $19 \cdot-5 "$ & $21^{\prime}-0^{\prime \prime}$ & $22 \cdot-5 "$ & $23^{\prime}-20^{\prime \prime}$ & $25^{\prime}-1^{\prime \prime}$ \\
\hline 3 & $1 / 2$ & $8^{\prime}-6 "$ & $12^{\prime}-0^{\prime \prime}$ & $14^{\prime}-9^{\prime \prime}$ & $17^{\circ}-0^{\prime \prime}$ & $19^{\prime}-0^{\prime \prime}$ & $20^{\prime}-9:$ & $22^{\prime}-6^{\prime \prime}$ & $24^{\prime}-0^{\prime \prime}$ & $25^{\prime}-6^{\prime \prime}$ & $26^{\prime}-10^{\prime \prime}$ \\
\hline 4 & & $9^{\prime}-0^{\prime \prime}$ & $12 \cdot-9 "$ & $15^{\prime}-7^{\prime \prime}$ & $18^{\circ}-0^{\prime \prime}$ & $20^{\prime}-2^{\prime \prime}$ & $22^{\prime}-0^{\prime \prime}$ & $23^{\prime}-10^{\prime \prime}$ & $25^{\prime}-6^{\prime \prime}$ & $27^{\prime}-0 . "$ & $25^{\prime}-5^{\prime \prime}$ \\
\hline
\end{tabular}

*THIS IS THE MINIMUM LENGTH OF PIPE WHICH SHOULD BE INSTALLED PERPENDICULAR TO THE DIREETIOY OE NOZZLE MOVENENT EETNEEN THE NOZZLE' AND THE FIRST PRESTRAINT WHICH AETS IN THAT DIRECRION. VOVEYENTS IN THREE ORTHOGONAL DIRECTIONS SHOULD BE CONSIDERED. 
TABLE A-4

RECONENDED OFFSET FOR ACCONODATION OF THERMAL EXPANSICA

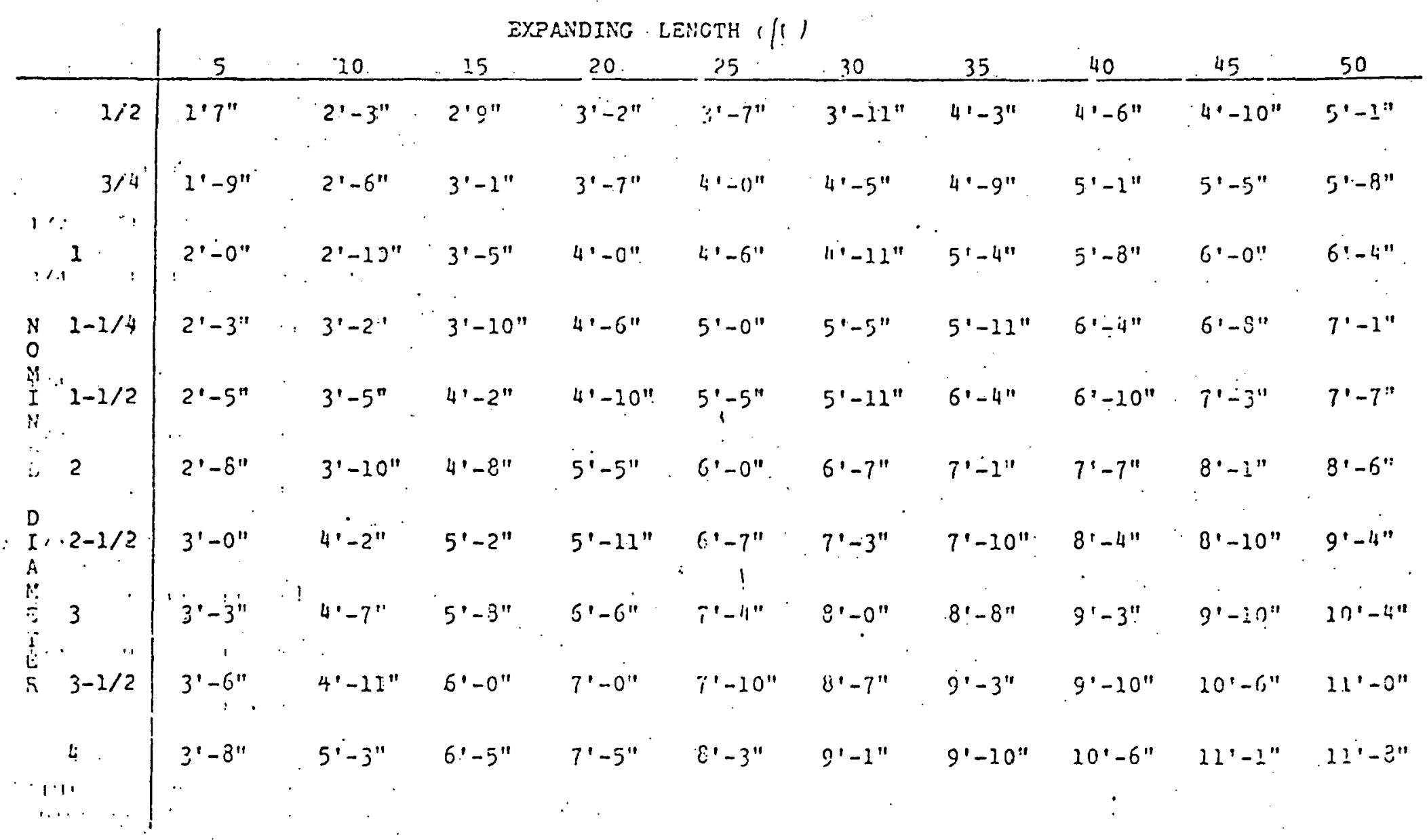


Nll equipment nozzles and header connections should be checked for movement in three (orthogonal) directions. The movenent in cach direction should be checked with Table D-i to determine the minimum acceptable offset. The offset is the total length of pipe which is perpendicular to the component of nozzle movement and lies between the nozzle and the first restraint which acts in the direction of that component. If that minimim is not met, an expansion loop must be acked or a restraint changed to non-rigid (spring or snubber). The thermal expansion worksheet serves as documentation for this process:

After all nozzle movements have been accomodated, thermal expansion of the pipe must be examined. The following procedure is recommended and is to be documented on the thermal expansiun worksheet.

l. Identify all adjacent pairs of parallel rigid restraints.

2. Find the total length of pipe between the rostraints of each pair with the pipe axis parallel to the dircction of restraint.

3. Use Table $D-2$ to determine the minimum acceptable offset for this length of pipe.

4. Find the total length of pipe between restraints with pipe. axis perpendicular to the direction of restraint.

5. Provide expansion loops if aecessary or changc supports to non-rigid types so that the value from 3 does not cxceed the the value from 4. 
APPENDIX B

RELIEF VALVE OPERATIONS

HYDRAULIC FORCE CALCULATIONS

$B-i$ 


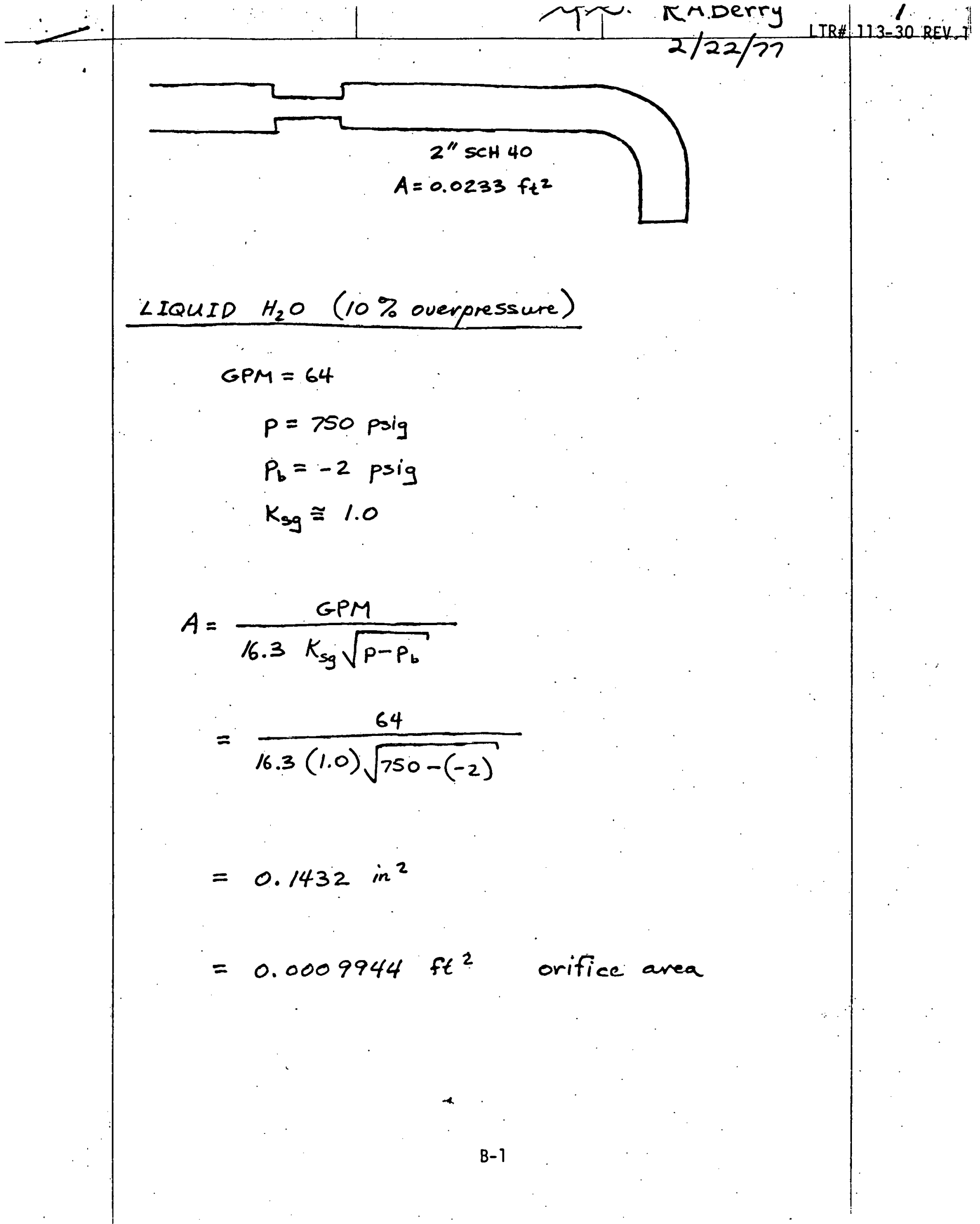




$$
\begin{aligned}
& \frac{\text { GASEOUS } N_{2}}{P_{0}=750^{\circ} \mathrm{ps}} \\
& \rho_{0}=3.766 \frac{16 \mathrm{~m}}{\mathrm{ft}^{3}} \\
& A=.0009944 \mathrm{ft}^{2} \\
& \omega=\dot{m} \\
& T_{0}=520^{\circ} R
\end{aligned}
$$

LIK\# IIs-su

REV.

Assuming isentropic flow - choked flow $\left(A^{*}=A\right)$ Fliegneris Formula (Assuming Air)

$$
\begin{aligned}
& \frac{\omega}{A^{*}} \frac{\sqrt{T_{0}}}{P_{0}}=0.532 \\
& \frac{\omega}{A^{*}}=0.532 \frac{(750)(144)}{\sqrt{520}} \\
& \frac{\omega}{A^{*}}=2520 \frac{\mathrm{lbm}}{\mathrm{sec} \mathrm{ft}^{2}} \\
& \omega=252.0(.0009944) \\
& \omega=2.506 \frac{16 \mathrm{~m}}{\mathrm{sec}} \\
& \rho^{*}=0.6339 . \\
& \rho_{0}^{*}=0.6339(3.766)=2.387 \frac{16 \mathrm{~m}}{\mathrm{ft}^{3}} \\
& Q^{*}=\frac{\omega}{\rho^{*}}=\frac{2.506}{2.387}=1.05 \frac{\mathrm{ft}^{3}}{\sec }
\end{aligned}
$$

B-? 


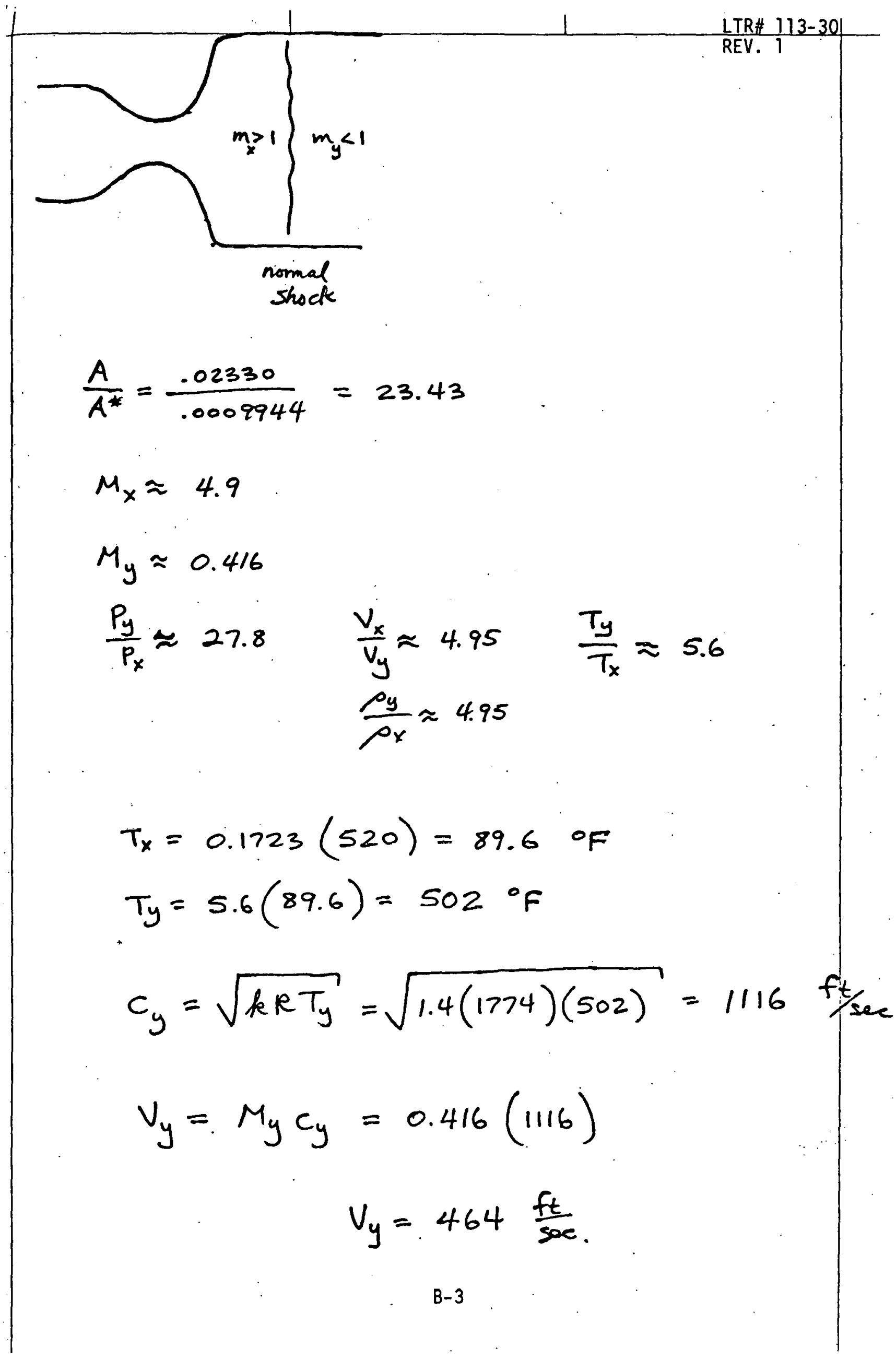

